DOI: http://dx.doi.org/10.33846/hn50504

http://heanoti.com/index.php/hn

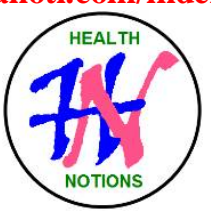

RESEARCH ARTICLE

URL of this article: http://heanoti.com/index.php/hn/article/view/hn50504

\title{
Gondomono (Hedycium spicatum) Ethanol Exstract Anti-Proliferation, Apoptosis and P53 Cancer Cell Line
}

\author{
Nur Rahman \\ Center of Excellence for Science and Technology on Local Materials for Handling Non-Communicable \\ Diseases, Poltekkes Kemenkes Malang, Indonesia; rahmancahaya@yahoo.com (Corresponding Author)
}

\begin{abstract}
The incidence of cancer from year to year continues to increase. Some of the causes of this incident include an unhealthy lifestyle, smoking, a diet high in fat and low in fiber. The Gondomono plant (Hedychium spicatum) are the most studied species. Interesting compounds have been identified like coronarin D, which possesses antibacterial, antifungal and antitumor activities, as well as isocoronarin $\mathrm{D}$, linalool and villosin that exhibit better cytotoxicity towards tumor cell lines than the reference compounds used, with villosin not affecting the non-tumor cell line. This study aims to obtain scientific evidence that Gondomono extract (Hedychium spicatum) is proven to be anti-cancer. The impact obtained will be utilized by local Indonesian plants that can be processed or produced as functional food and herbal medicine for anti-cancer bioactivity toxicity with various tests including the making gondomono (Hedycium spicatum) flour, ethanol extraction method, insilico analysis and Gas ChromatographyMass Spectrometry (GC-MS) analysis, then the second stage test, namely the MTT test, P53 test and apoptosis test. The research design was experimental. Gondomono extract when compared to anticancer ingredients was indeed very far away, gondomono extract was starting to be able to act as apoptosis, it requires a fairly high concentration, from 200 to $400 \mathrm{ppm}$. As conclusion, the higher the dose of gondomono extract, the higher the expression of p53 protein, the higher. Gondomono extract as a cancer cell killer requires a minimum dose of $368.51 \mathrm{ppm}$.
\end{abstract}

Keywords: gondomono; Hedycium spicatum; anti-proliferasi; cancer cell line

\section{INTRODUCTION}

\section{Background}

The incidence of cancer from year to year continues to increase, in 1996 there were 10 million new cases, and of these cases 6 million died, it is estimated that in 2020 new cancer cases will be 20 million and 12 million died. Some of the causes of this incident include an unhealthy lifestyle, smoking, a diet high in fat and low in fiber (1). Breast cancer is a cancer that is the leading cause of death, with $23 \%$ of cases and $14 \%$ of deaths, while the second place is lung cancer, with $17 \%$ of lung cancer cases and $23 \%$ of deaths ${ }^{(2)}$.

In the United States as a developed country, cancer is the second leading cause of death (23.1\%) after heart disease (26\%). In the group of women, breast cancer is the second cause of death (15\%) after lung cancer (26\%). In the male group, lung cancer is the first cause of death (30\%). There is a tendency that from year to year the death rate due to cancer continues to increase, starting in 1930 by 50,000 people and in 2006 to 280,000 people ${ }^{(3)}$.

In 2010, the prevalence of tumor/cancer in Indonesia was 1.4\%. Among non-communicable diseases, cancer is in the 4th rank, equivalent to diabetes mellitus with a prevalence of $10.2 \%(\mathrm{n}=2,285)$ after stroke, hypertension, and ischemic heart disease. Cancer is the 6th cause of death, equivalent to diabetes mellitus by $5.7 \%$ after stroke, tuberculosis, hypertension, injury and perinatal disease ${ }^{(4)}$. The number of cancer patients in Indonesia is estimated to continue to increase from year to year with an estimated number of 12 million people in 2030.WHO also said that every year there are around 6.25 million people with new cancer and this number will continue to increase if there is no treatment action. and prevention of cancer ${ }^{(5)}$.

The results showed that consuming a diet high in fruit and vegetables will fight cancer. From the results of 200 studies stated that vegetables and fruit were significantly found 128-156 studies associated with a reduced risk of cancer. The results also show that consumption of vegetables and fruit can reduce approximately 20-23 
percent of lung cancer ${ }^{(6)}$. Therefore, based on the description above, a research on the potential of plant mixture extracts as anti-proliferation of cancer cells will be carried out.

\section{Purpose}

The long-term objective of this study was to obtain a method of extracting plant mixtures, as well as obtaining scientific evidence that mixed plant extracts can be used as an anti-cancer prevention.

\section{Design}

\section{METHODS}

This study was an laboratory research. The research was conducted from June to December 2016 in the laboratory of UIN Malang, Brawijaya University biomedical laboratory, UM chemistry laboratory, and Polinema chemistry laboratory. The material used was a healthy, green, gondomono plant (Hedycium spicatum) taken from the Batu area, East Java.

\section{Testing Phase 1}

\section{Making Gondomono (Hedycium spicatum) Flour}

Weighing $1 \mathrm{~kg}$ of gondomono (Hedycium spicatum) plants, oven at $55^{\circ} \mathrm{C}$ for 1 day. After drying, the gondomono plants were ground in a blender and sieved. Furthermore, the gondomono flour would be extracted with ethanol ${ }^{(7)}$.

\section{Ethanol Extraction Method}

Weighing $100 \mathrm{~g}$ of gondomono flour that had been smooth. Then extract (macerated) with ethanol $70 \% 7$ $\mathrm{x}$ dry matter $(50 \mathrm{~g})$, with stirring for 2 hours and left to stand for 1 night. The solution was then filtered with Whatman filter paper No. 1, the solvent was removed or evaporated by an evaporator at a temperature of $50^{\circ} \mathrm{C}^{(8)}$.

$\underline{\text { Insiloco Analysis }}$

Analysis of biological activities based on the value of Probability activity (Pa) with a value range of 0 to 1. Using tools: PyMol and PyRx ${ }^{(9)}$.

\section{Gas Chromatography-Mass Spectrometry (GC-MS) Analysis}

Determination of the structure of the compounds of gondomono (Hedycium spicatum) was carried out using a GS-MS spectrometer. The analysis was performed using GC-MS Agilent 6.890 N 2006 with 5 MS DB column dimensions of $30 \mathrm{~m} \times 250 \mu \mathrm{m} \times 0.25 \mu \mathrm{m}$. The system conditions were oven temperature $310^{\circ} \mathrm{C}$, detector $310^{\circ} \mathrm{C}$, injector $305^{\circ} \mathrm{C}$, program temperature (initial $50^{\circ} \mathrm{C}$, increase of $3.50^{\circ} \mathrm{C}$ per minute to a maximum temperature of $310^{\circ} \mathrm{C}$ ), analysis time 100 minutes, column pressure 14.12 psi with a flow rate of $1.7 \mathrm{~mL}$ per minute and an injection volume of $2 \mu \mathrm{L}^{(10)}$.

\section{Testing Phase 2}

\section{MTT Test Method}

This study aimed to examine the inhibition of gondomono extract against the proliferation of servic cancer cells, using the MTT (3- (4,5-dimethylthiazol-2,5-diphenyltetrazolium bromide) method. The MTT method was used to determine which cells are still alive. In measuring the color change by measuring the activity of an enzyme that reduced MTT to formazan which gives a purple color MTT yellow dye reduced the purple color of formazan in living cells ${ }^{(11)}$. Cancer cells in complete medium (DMEM) were added with fetal bovine serum $10 \%$. Penicillin $100 \mu / \mathrm{ml}$ and streptomycin $100 \mu \mathrm{g} / \mathrm{ml}$ ) were cultured for 24 hours. After the cell density reached about $50 \%$, the cultures were further incubated for 48 hours with or without extract treatment at concentrations of 25, 50, 100, 200, 400, 800 ppm medium with IC50. Testing the inhibitory activity of cancer cells was measured by an ELISA reader at a wavelength of $570 \mathrm{~nm}^{(12)}$. The positive control used docsorubin with concentrations of $0.005,0.1,0.5$ $1,5,10,25,50,100 \mathrm{nM}^{(13)}$.

\section{P53 Test}

The p53 protein is a tumor suppressor protein that acts as a regulator of the cell cycle. The p53 protein plays an important role in the response to cellular stress, such as exposure to carcinogens. This protein will inhibit the proliferation of abnormal cells that have been initiated by carcinogens to prevent the development of neoplasms. The inactivity of these proteins can cause malignancy to malignant cancer. Besides functioning to 
regulate cell proliferation, p53 also regulates apoptosis, inhibits angiogenesis, and regulates DNA repairment. In cancer, generally p53 has a mutation. The most common p53 mutation is missense mutation. These mutations can be in the form of p53 degradation, loss of p53's ability to induce cell cycle arrest or apoptosis, and loss of p53's affinity for binding to damaged DNA. Immunohistochemistry is a process of identifying specific proteins in tissues or cells using antibodies. The site of binding between antibodies and specific proteins is identified by markers that are usually attached to the antibody and can be visualized directly or by reaction to identify markers. Markers can be colored compounds, fluorescent substances, heavy metals, radioactive labels, or enzymes ${ }^{(14)}$.

\section{Apoptosis Test}

A number of cover slips were prepared and then inserted into the 24 wells microplate. The number of cell suspensions ( 5 x 105 cells) in complete culture media was transferred as much as $1 \mathrm{ml}$ onto the cover slip. The distributed cells were put in a $\mathrm{CO}_{2}$ incubator at $37^{\circ} \mathrm{C}$ overnight. After one night, the media containing the cells was discarded and the test sample was inserted into the well as much as $1 \mathrm{ml}$. The microplates were then incubated for 10 hours in a $\mathrm{CO}_{2}$ incubator. The microplates that have been incubated are removed from the incubator and then the media in the well is discarded. The cells in the well were washed with $1 \mathrm{ml}$ of PBS. PBS from the well removed with a micropipette slowly. The cover slip was carefully removed and then placed on the glass object. A total of $10 \mu \mathrm{l}$ of reagent mixture of ethidium bromide - acridine orange was dropped on the cover slip. The cells were then observed under a fluorocene microscope (Olympus) ${ }^{(15)}$.

\section{Qualitative Test}

\section{RESULTS}

Table 1 shows that the Gondomono extract qualitatively contained flavomoid, alkaloid and saponin ingredients.

Table 1. Gondomono extract qualitative test results

\begin{tabular}{ccc}
\hline No & Parameter & Result \\
\hline 1 & Flavonoid compounds & Positive \\
2 & Alkaloid compounds & Negative \\
3 & Saponin compounds & Negative \\
\hline
\end{tabular}

\section{Antioxidant Activity Quantitative Test}

Table 2. Antioxidant activity of gondomono extract

\begin{tabular}{|c|c|c|c|c|}
\hline \multirow{2}{*}{ Concentration (ppm) } & \multicolumn{3}{|c|}{ \% Inhibition (Repeat) } & \multirow{2}{*}{ Average } \\
\hline & I & II & III & \\
\hline 24 & 7.26 & 8.33 & 8.38 & 7.99 \\
\hline 48 & 17.32 & 17.78 & 17.88 & 17.65 \\
\hline 72 & 26.82 & 28.33 & 26.26 & 27.13 \\
\hline 96 & 32.96 & 33.89 & 32.96 & 33.27 \\
\hline 120 & 38.55 & 40.00 & 39.11 & 39.21 \\
\hline IC50 (ppm) & 149.99 & 145.51 & 150.65 & 148.72 \\
\hline
\end{tabular}

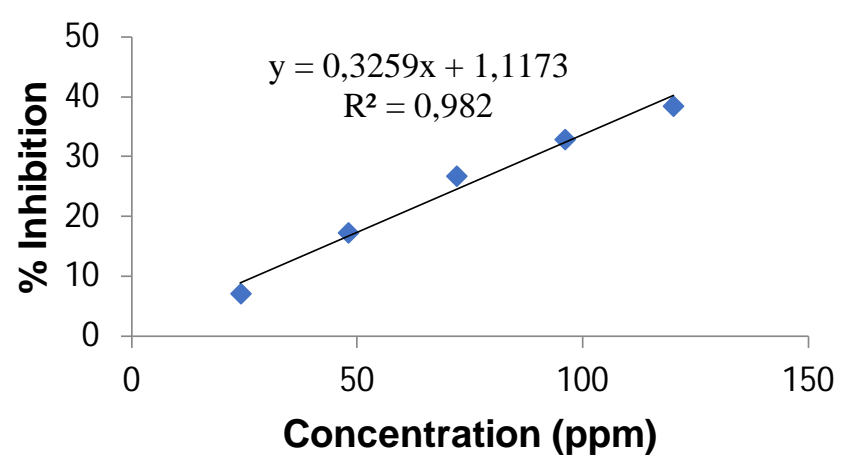

Figure 1. Antioxidant activity of gondomono extract

In table 2 it can be seen that the Gondomono extract had an IC50 of 148.72 


\section{Bioactive Component Test}

Intensity

Chromatogram G D:IGC-MSL2016\POLTEKESLNURAKHMANIGS.qgd

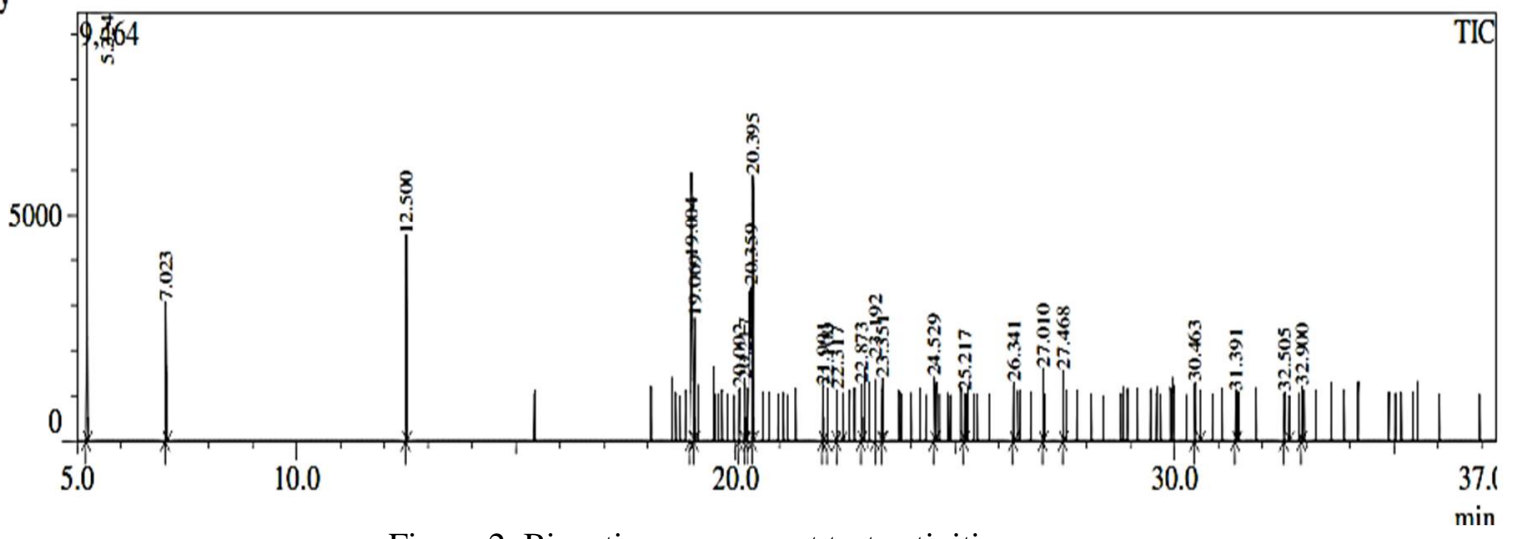

Figure 2. Bioactive component test activities

$\begin{array}{rr}\text { Peak\# } & \text { R.Time } \\ 1 & 5.224 \\ 2 & 7.023 \\ 3 & 12.500 \\ 4 & 19.004 \\ 5 & 19.069 \\ 6 & 20.092 \\ 7 & 20.217 \\ 8 & 20.359 \\ 9 & 20.395 \\ 10 & 21.991 \\ 11 & 22.100 \\ 12 & 22.317 \\ 13 & 22.873 \\ 14 & 23.192 \\ 15 & 23.351 \\ 16 & 24.529 \\ 17 & 25.217 \\ 18 & 26.341 \\ 19 & 27.010 \\ 20 & 27.468 \\ 21 & 30.463 \\ 22 & 31.391 \\ 23 & 32.505 \\ 24 & 32.900\end{array}$

$\begin{array}{rr}\text { Area } & \text { Area\% } \\ 14659 & 15.44 \\ 4805 & 5.06 \\ 5264 & 5.54 \\ 13779 & 14.51 \\ 3266 & 3.44 \\ 1152 & 1.21 \\ 1814 & 1.91 \\ 11958 & 12.60 \\ 10952 & 11.54 \\ 1647 & 1.73 \\ 1166 & 1.23 \\ 1099 & 1.16 \\ 1726 & 1.82 \\ 1219 & 1.28 \\ 1863 & 1.96 \\ 2544 & 2.68 \\ 1560 & 1.64 \\ 1813 & 1.91 \\ 1993 & 2.10 \\ 1924 & 2.03 \\ 2378 & 2.50 \\ 2660 & 2.80 \\ 2059 & 2.17 \\ 1635 & 1.72 \\ 94935 & 100.00\end{array}$

$\begin{array}{ccc}\text { Peight } & \begin{array}{c}\text { Peak Report TIC } \\ \text { Height } \%\end{array} & \text { A } 1 \text { H } \\ 9464 & 17.27 & 1.54 \\ 3063 & 5.59 & 1.56 \\ 4558 & 8.32 & 1.15 \\ 4024 & 7.34 & 3.42 \\ 2720 & 4.96 & 1.20 \\ 1185 & 2.16 & 0.97 \\ 1331 & 2.43 & 1.36 \\ 3406 & 6.21 & 3.51 \\ 5887 & 10.74 & 1.86 \\ 1220 & 2.23 & 1.35 \\ 1183 & 2.16 & 0.98 \\ 1128 & 2.06 & 0.97 \\ 1253 & 2.29 & 1.37 \\ 1359 & 2.48 & 0.89 \\ 1397 & 2.55 & 1.33 \\ 1404 & 2.56 & 1.81 \\ 1065 & 1.94 & 1.46 \\ 1292 & 2.36 & 1.40 \\ 1612 & 2.94 & 1.23 \\ 1564 & 2.85 & 1.23 \\ 1291 & 2.36 & 1.84 \\ 1098 & 2.00 & 2.42 \\ 1093 & 1.99 & 1.88 \\ 1207 & 2.20 & 1.35 \\ 54804 & 100.00 & \end{array}$

Figure 3. Bioactive component test activities

[Cocrument]

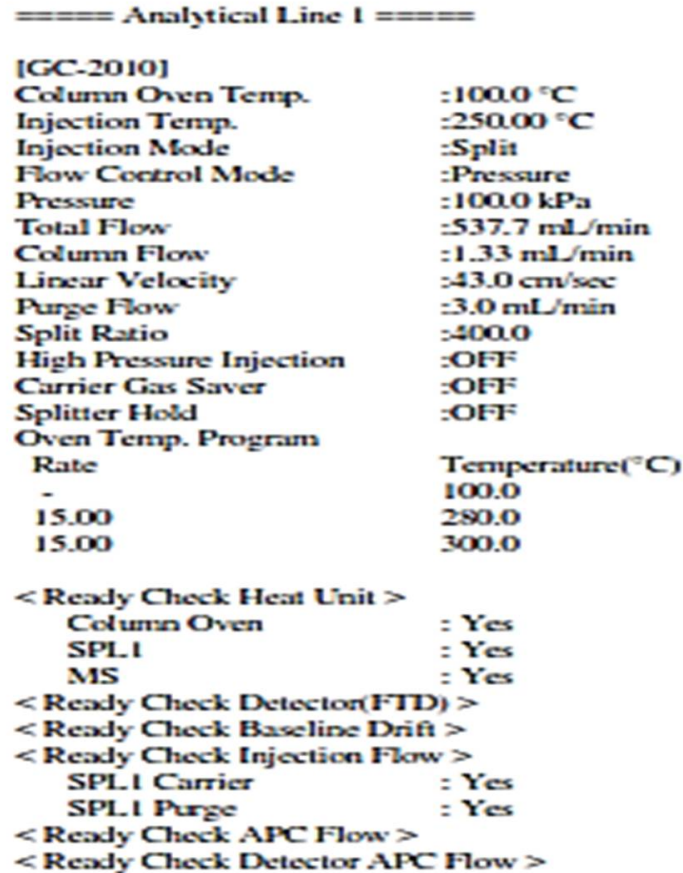

Hold Timermin)

200

20.00

Figure 4. Bioactive component test activities

166 | Publisher: Humanistic Network for Science and Technology 


\section{MTT Proliferation Test}

Table 3. MTT method proliferation test results

\begin{tabular}{ccc}
\hline No & Concentration $(\mathrm{ppm})$ & Percent cell death \\
\hline 1 & 25 & 6.27 \\
2 & 50 & 10.380 \\
3 & 100 & 1.81 \\
4 & 200 & 14.506 \\
5 & 400 & 89.88 \\
6 & 800 & 93.63 \\
7 & Cisplastin $(17.1 \mathrm{ug} / \mathrm{ml}$ & 86.82 \\
\hline
\end{tabular}

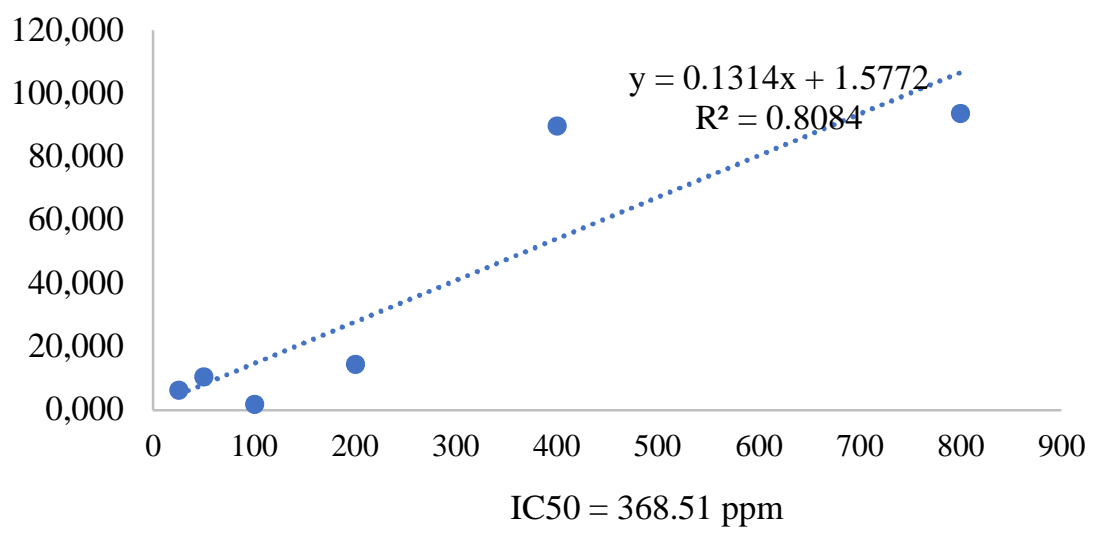

Figure 5. MTT method proliferation test

In Figure 5, it can be seen that the IC50 value of the Gondomono extract was $368.51 \mathrm{ppm}$, this value was sufficient (note: good if the IC50 value is below $300 \mathrm{ppm}$ ).

\section{Apoptosis Test With FITC Anexin Method}

Table 4. Apoptosis test with FITC anexin method result

\begin{tabular}{cccccc}
\hline & \multicolumn{3}{c}{ Concentration (PPM) } & \multirow{2}{*}{ Avarage } \\
\cline { 2 - 5 } & I & II & III & IV & \\
\hline 0 & 1.56 & 1.95 & 2.63 & 1.95 & \\
25 & 2.03 & 1.88 & 1.46 & 1.71 & \\
50 & 1.81 & 1.85 & 1.93 & 1.87 & \\
100 & 2.78 & 2.90 & 2.82 & 3.27 & \\
200 & 13.59 & 7.35 & 7.09 & 10.30 & \\
400 & 78.79 & 86.90 & 86.68 & 86.50 & \\
800 & 90.05 & 89.99 & 90.00 & 89.64 & \\
$\mathrm{~K}+$ & 70.97 & 71.01 & 67.02 & 66.32 & \\
\hline
\end{tabular}

In Table 4, it can be seen that giving a concentration between 200 to 400 could kill cancer cells which was equivalent to a positive control, namely the could kill cancer cells by $84.7 \%$.

\section{P53 Test}

Table 5. P53 Test Result

\begin{tabular}{cccccc}
\hline & \multicolumn{3}{c}{ Concentration (PPM) } & \multirow{2}{*}{ Avarage } \\
\cline { 2 - 4 } & I & II & III & IV & \\
\hline 0 & 64.41 & 62.10 & 62.17 & 59.21 & \\
25 & 64.41 & 62.10 & 73.27 & 77.18 & \\
50 & 75.72 & 75.60 & 81.26 & 81.87 & \\
100 & 95.49 & 94.73 & 95.26 & 96.11 & \\
200 & 88.94 & 90.41 & 93.56 & 91.70 & \\
400 & 90.12 & 90.41 & 87.29 & 89.02 & \\
800 & 98.81 & 98.80 & 98.68 & 99.15 & \\
K+ & 32.77 & 26.90 & 49.81 & 55.45 & \\
\hline
\end{tabular}



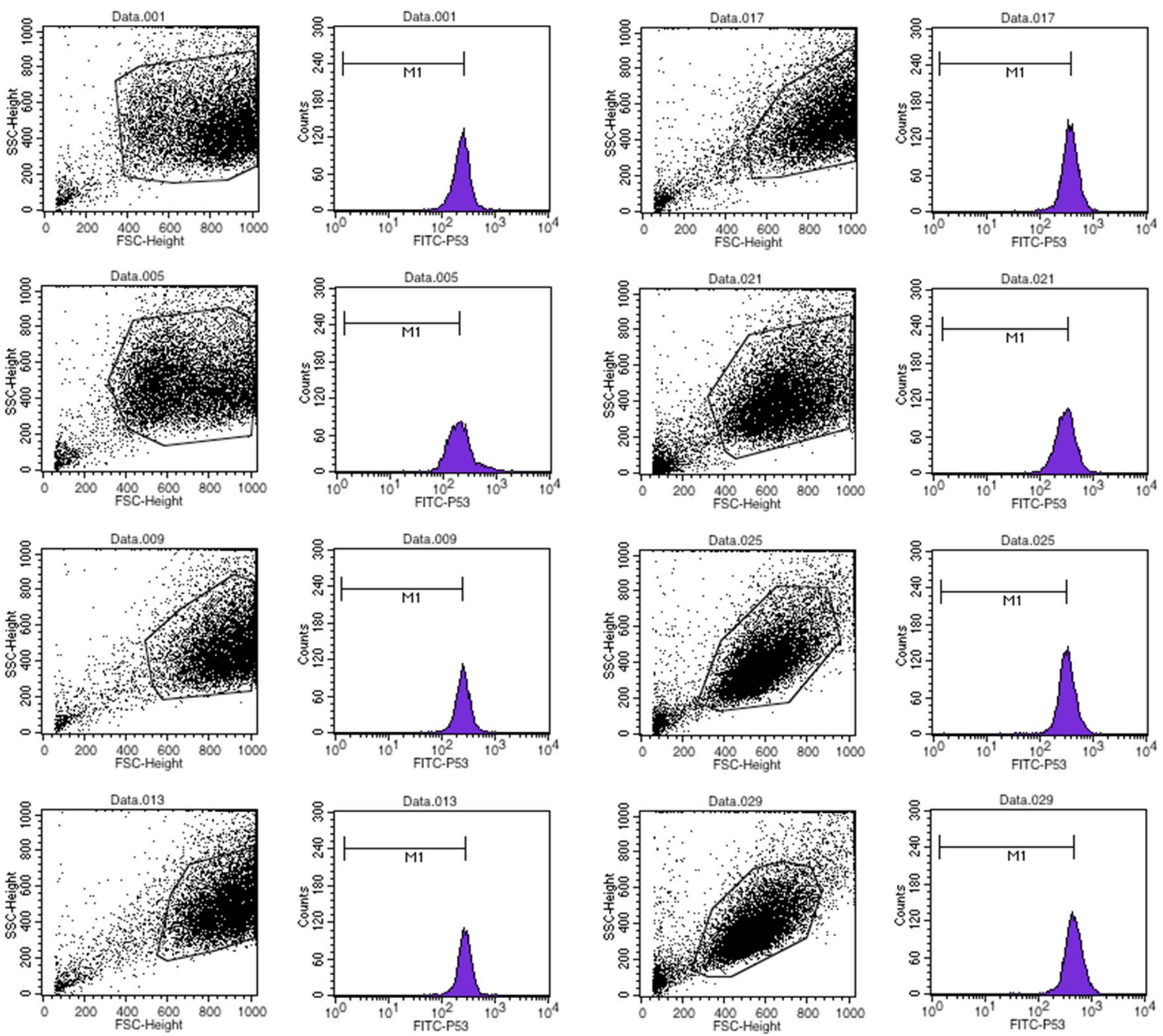

Figure 6. P53 test activity

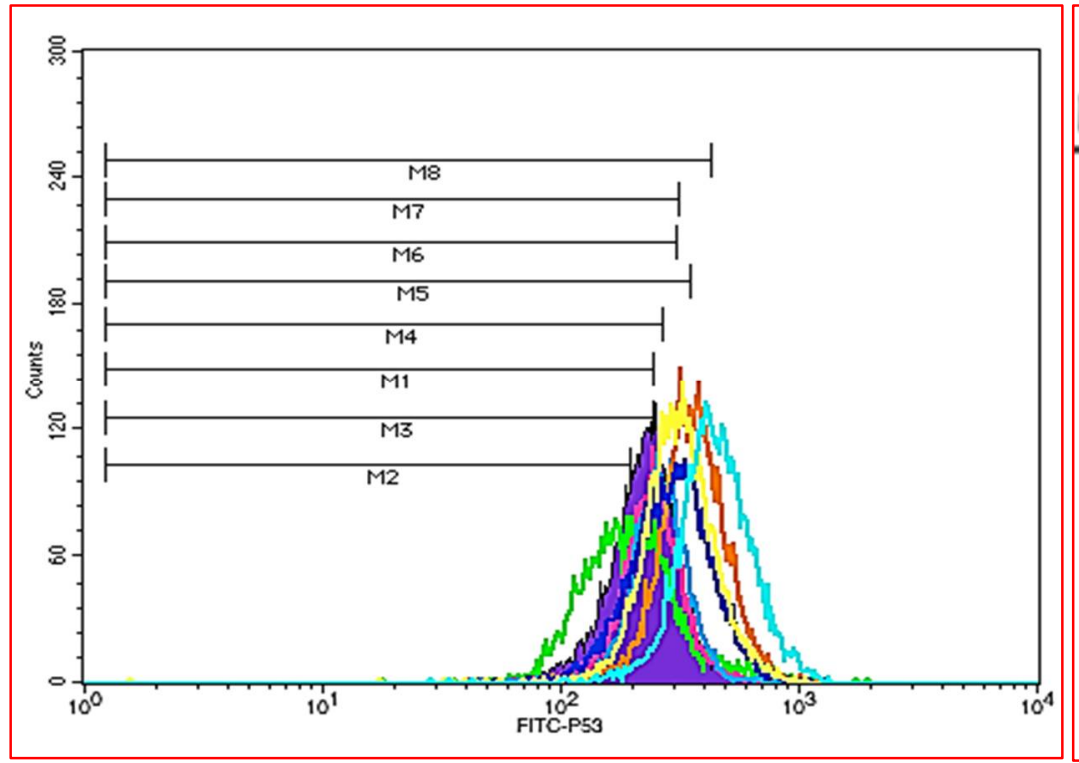

Marker Events \%Gated \% Tota

$\begin{array}{llll}\text { All } & 85.15 & 100.00 & 73.47\end{array}$

III $\quad 5504 \quad 64.41 \quad 47.32$

$\begin{array}{llll}\text { III } & 2800 & 32.77 & 24.07\end{array}$

$\begin{array}{llll}\text { IB } & 5504 & 61.41 & 47.32\end{array}$

IM $\quad 6470 \quad 75.72 \quad 55.63$

$\begin{array}{llll}145 & 8160 & 95.49 & 70.16\end{array}$

15. $7600 \quad 88.94 \quad 65.34$

$\begin{array}{llll}\text { II } & 7701 \quad 90.12 \quad 66.21\end{array}$

$\begin{array}{llll}18 & 8443 \quad 98.81 \quad 72.59\end{array}$

Figure 7. P53 Test Activity

168 | Publisher: Humanistic Network for Science and Technology 


\section{DISCUSSION}

The results of the qualitative analysis showed that the gondomono extract contained flavonoids, alkaloids and saponin components. Gondomono extract has an IC50 of $148.72 \mathrm{ppm}$. Gondomono extract has an IC50 of $148.72 \mathrm{ppm}$. IC 50 on cancer cells of Gondomono extract was $368.51 \mathrm{ppm}$. The effect of giving gondomono extract will affect the apoptosis value, with positive control with a dose of $1.7 \mathrm{ppm}$, the apoptosis value is $68 \%$, with the provision of gondomono extract the apoptosis value is around 84.8 at a dose of $400 \mathrm{ppm}$, when compared with the standard apoptosis value is very far.

Gondomono extract when compared to anticancer ingredients is indeed very far away, gondomono extract is starting to be able to act as apoptosis, it requires a fairly high concentration, from 200 to $400 \mathrm{ppm}$. The p53 protein expression indicates a stress cell response. Decrease in p53 protein can cause a decrease in the mechanism of apoptotic cells.

\section{CONCLUSION}

The dose of gondomono extract, the higher the expression of p53 protein, the more likely it is to increase, which indicates an apoptotic process. Likewise, the higher the dose of gondomono extract, the higher the expression of p53 protein, the higher. Gondomono extract as a cancer cell killer requires a minimum dose of $368.51 \mathrm{ppm}$.

\section{REFERENCES}

1. Alison MR. Cancer. Nat Publ Gr. 2001.

2. Jemal A, Bray F, Ferlay J. Global Cancer Statistics: 2011. CA Cancer J Clin. 1999;49(2):1,33-64.

3. Heron M. Deaths: Leading Causes for 2008. Natl Vital Stat Rep. 2012;60(6):1-94.

4. Kemenkes RI. Riset Kesehatan Dasar 2013. Jakarta: Kemenkes RI; 2013.

5. World Health Organization. Policy and Advocacy (Cancer Control: Knowledge into Action: WHO Guide for Effective Programmes: Module 6). Geneva: WHO; 2008.

6. Donaldson MS. Nutrition and Cancer: A Review of the Evidence for an Anti-cancer Diet. Nutr J. 2004;3:121.

7. Wetwitayaklung P, Phaechamud T, Keokitichai S. The Antioxidant Activity of Caesalpinia sappan 1. Heartwood in Various Ages. Naresuan Univ J. 2005;13(2):43-52.

8. Pérez-Amador MC, Ocotero VM, Castañeda JMG, Esquinca ARG. Alkaloids in Solanum torvum Sw (Solanaceae). Phyton (B Aires). 2007;76:39-45.

9. Narwanto MI, Rahayu M, Soeharto S, Nurdiana N, Widodo MA. Identification and in Silico Analysis of Anti Inflammation and Anti Oxidant Potentials of Polyphenol Compounds in Methanol Extract of Tamarindus indica Seeds. J Agromedicine Med Sci. 2018;4(1):13.

10. Yuhendri, Jasril, Yuharmen. Isolasi dan Uji Toksisitas Metabolit Sekunder Ekstrak n-Heksana Kulit Batang Tumbuhan Polyalthia pulchra var. angustifolia King (Annonaceae). Pekanbaru: FMIPA Univ Riau. 2013.

11. Mosmann T. Rapid Colorimetric Assay for Cellular Growth and Survival: Application to Proliferation and Cytotoxicity Assays. J Immunol Methods. 1983;65(1-2):55-63.

12. Wahyuni S, Zakaria F, Witarto AB, Syah D, Suhartono M. Aktivitas Anti Kanker Senyawa-Senyawa Kitooligomer. Jurnal Teknologi dan Industri Pangan. 2006;17:12-22.

13. Abu-Dahab R, Afifi F. Antiproliferative Activity of Selected Medicinal Plants of Jordan against a Breast Adenocarcinoma Cell Line (MCF7). Sci Pharm. 2007;75(3):121-36.

14. Fakultas Farmasi UGM. Chemoprevention Research Center (CCRC). Yogyakarta: Fakultas Farmasi UGM.

15. Kwan YP, Saito T, Ibrahim D, Al-Hassan FMS, Ein Oon C, Chen Y, et al. Evaluation of the Cytotoxicity, Cell-cycle arrest, and Apoptotic Induction by Euphorbia hirta in MCF-7 Breast Cancer Cells. Pharm Biol. 2016;54(7):1223-36. 